\title{
9
}

\section{Milestone programs for the administrative service in the Singapore Public Service}

\author{
James Low ${ }^{1}$
}

\section{Scope and approach}

This chapter examines executive training in the Singapore Public Service: who are the people behind the executive leadership of the Singapore bureaucracy? What is their training? Who conducts the training? How does this training build capacity in the Singaporean bureaucracy? By addressing these questions, this chapter seeks to enlarge the existing body of knowledge, especially in light of the current dearth of literature on the subject of training in the Singapore Public Service and the country's public administration.

For meaningful discussion, this chapter focuses on the role of centralised training. In Singapore, bureaucracy training is undertaken centrally and at the various agencies of the public service. Agencybased training includes content catering to specific portfolio needs such as the use of specialised equipment (for example, firearms in the

1 Thanks to Professor John Wanna, Professor Hon S. Chan, Professor Andrew Podger and other colleagues for their guidance in writing this chapter. While all their suggestions were instrumental in shaping the arguments herein, I bear responsibility for the chapter, including all errors that may arise. 
military and police) or inducting officers into peculiar organisational culture (for example, regimentation in uniformed services). Some agencies also have informal mentorship or coaching programs as part of leadership development efforts. Individual officers may also be sent for postgraduate courses in universities. Making an inventory of all such non-centralised training, from executive programs and coaching for individual officers to agency-based courses, will undoubtedly be a complex exercise. More importantly, such non-centralised training is not reflective of developments across the bureaucracy and cannot be meaningful for cross-bureaucratic analysis. Rather, this chapter will focus on centralised training to explore the role of executive training in the context of the Singapore Public Service.

While official government records on the Singapore bureaucracy are not readily available, a mine of official information can be found in the public domain. The challenge lies in accessing official documents recording decision-making - commonly available in the archives of countries such as Australia, the United Kingdom and the United States under freedom of information legislation. Such is the nature of the Singapore Administrative Service that detailed official information is scant. Nevertheless, the approach in this inquiry is to trawl for data in the open domain for primary sources. Records such as annual reports, curriculum material and information brochures found at the National Archives of Singapore, the National University of Singapore Library and Singapore's National Library provide useful primary materials. News reports can cross-reference other primary records. Data from previous research such as interviews of officials by undergraduates for their academic tasks, found at the National University of Singapore, will also be drawn on.

The discussion that follows will begin with a historical and political background of the Singapore Public Service before introducing the Administrative Service - the executive leadership of the bureaucracy. It will then address the key subject of the chapter: the training of Administrative Service Officers (AOs). The topic will be elaborated on by identifying the Civil Service College (CSC) and its Institute of Policy Development (IPD) as the centres through which AOs are trained. The focus is then on Milestone Programs - the system of continuous training throughout the careers of AOs. By attuning AOs to the policy milieu, Milestone Programs build up AOs' capacity to formulate and implement policies. In other words, the training is responsive to the 
context of the work of AOs. More importantly, this chapter shows that by helping to attract the best and brightest to provide leadership for the bureaucracy, Milestone Programs contribute to developing Singapore's capacity for effective governance.

\section{The Singapore Public Service: Background}

Singapore today, with its high standard of living and economic vibrancy, has come a long way since gaining self-government in 1959 after 140 years of British colonial rule. A small island (710 sq km) without natural resources, relying on imports for all essentials, it generates an impressive gross domestic product (GDP) of $\mathrm{S} \$ 304$ billion ( $\mathrm{A} \$ 297.3$ billion). This is a more than 145 per cent increase from the figure at decolonisation; per capita GDP has also grown 45 per cent since 1959 to $\$ \$ 57,603(\mathrm{~A} \$ 56,300)$. Unemployment is a low 2.1 per cent; infant mortality is only two per 1,000 live births; and the literacy rate is 97 per cent. Singapore's multiracial population - an ethnic Chinese majority and substantial Indian and Malay communities - lives in general harmony and the crime rate is low. This stability and modern amenities make Singapore one of the most liveable cities in the world.

The Singapore Public Service is often given little credit for the leading role it played in the country's modernisation. Singapore's transformation is typically attributed to the strategic foresight and political will of founding prime minister, Lee Kuan Yew, and his colleagues in the People's Action Party (PAP) (see, for example, Turnbull 1989; Drysdale 1984; Chew and Lee 1991; Lam and Tan 1999; Tan 2007; Latif 2009; Ng 2010; Ho 2000: 149). There were scholars who argued that the public service was made up of civil servants wielding 'power and privilege without accountability to the public and who may eventually become the real rulers of the country' (Chan 1975: 68; see also Seah 1999: 253). Proponents of this 'administrative state' model were really pointing to the bureaucracy as a source from which the ruling party coopted talent. The credit for Singapore's development continued to be accorded to the political elite.

Political visions, however, had to be translated into policies - and this depended on the bureaucracy. Singapore's early strategy to attract foreign investment needed civil servants to market the fledgling 
state across the world to draw in overseas capital. Engineers were responsible for erecting factories to make industrialisation a reality. Improving living standards required architects to plan new public housing zones, doctors and nurses to administer primary health care and teachers to provide education. Even as the maturing state sought infrastructural expansion and more sophisticated economic strategies, converting these broad strategic ideas into actionable policies, and then carrying them out, rested on the shoulders of the country's civil servants, from senior bureaucrats to rank-and-file frontline officers. Significant credit for Singapore's modernisation is due to the public service, which turned the strategic foresight of the political elite into reality.

The Singapore Public Service today is regarded as 'one of the most efficient and least corrupt in the world' by the UN Public Administration Network (UNPAN 2005) and other international indicators. ${ }^{2}$ Unlike counterparts in some post-colonial states, Singapore's bureaucracy and its leadership have not interfered in the political arena. Unique even to civil services of developed countries, the Singapore Public Service has gone beyond efficiency and integrity to position its officers to 'anticipate, welcome and execute change' (PSD 2011). From harnessing technology to delivering government services, it has gone on to adopt concepts and tools such as scenario planning and horizon scanning to prepare for unforeseen crises that may arise in the future - a sign of its growing sophistication. Efficient, incorrupt and faceless behind its political masters, the Singapore Public Service is quintessentially 'professional' by Westminster standards.

A large body of literature covers various aspects of this professionalism. Quah has written extensively on the bureaucracy's management of personnel, particularly through the Public Service Commission, and the fight against corruption. ${ }^{3}$ Quah (1987) also studied the bureaucracy's ability to implement policies formulated by the political leadership and his 1985 work covered statutory boards, a subject also addressed by Lee (1975). Recent works by other scholars analyse administrative reforms, such as those by Koh (1997) and Jones (2002) (see also Quah

2 Under 'Institutions', Singapore ranked first of 133 countries from 1999 to 2011 (World Economic Forum 2011: 4, 14).

3 On the Public Service Commission, see Quah (1971; 1972; 1996a: 492-506). On corruption, see Quah (1978; 1989: 841-53; 2003: 180-97). 
1994, 1996b). In 2010, Quah published Public Administration Singapore Style, compiling themes of his work thus far: statutory boards, the Public Service Commission, compensation, bureaucratic reforms and anti-corruption efforts.

Yet the role of training in this professionalism is virtually ignored in the public administration literature. As Simon (1976) points out, training - by preparing staff to reach satisfactory decisions on their own - frees the organisation from the constant exercise of authority. Giving officers the knowledge and loyalty to act in the organisation's interests but using their own discretion is especially critical for large organisations dispersed across different locations. Training thus allows a bureaucracy to carry out daily functions effectively. Yet the importance of the subject is not matched by the significance accorded it in Singaporean public administration literature. Training has largely been discussed as part of broader topics such as personnel management. There are two rather comprehensive perspectives on training within larger discussions - namely, Seah (1971) and Lee (1977) — and several undergraduate theses (Sim 1985; Lai 1995; Siow 1998), but these are outdated.

\section{From colonial bureaucracy to the Singapore Public Service}

The genesis of the Singapore Public Service is in a colonial bureaucracy that was discriminatory and disconnected from the populace. The administration set up after the island's 1819 colonisation restricted executive positions to 'natural-born British subjects of pure European descent on both sides' (Seah 1971: 12). Locals could only fill rankand-file positions, working as policemen, peons, clerks and the like. Even when tertiary education qualified locals for higher positions, their service conditions never matched those of their European colleagues. European officers, despite effectively governing the colony, did not receive any training preparing them to govern. Courses in administration before their overseas deployment equipped them for general service across the British Empire rather than in specific colonies. British bureaucrats thus arrived in Singapore without an understanding of the local population and culture. 
Discriminatory staffing only ended towards the end of the colonial period. In 1957, after years of agitation for localisation of the bureaucracy, barriers against local officers being promoted into the elite Administrative Service were at last removed. ${ }^{4}$ A century after the Northcote-Trevelyan reforms required the British Civil Service to make appointments based on an individual's qualifications, deserving local officers in Singapore were finally able to access the apex of the bureaucracy. Besides the consolidation of wide-ranging schemes of service into four divisions (see Seah 1971: 30), the introduction of meritocracy represents the most enduring bureaucratic reform of the colonial era. Meritocracy continues to be the guiding principle for recruitment and promotion in the present-day Singapore Public Service.

The bureaucracy's aloofness from the populace did not improve even late in the colonial period. As a colonial institution, the bureaucracy had long regarded itself as a sovereign's agent ruling over imperial subjects. Even local rank-and-file civil servants were generally overbearing and rude towards the local people; street-level bureaucrats such as police and postmen were notorious for petty corruption. Senior civil servants, on the other hand, were typically sequestered in offices away from the 'man on the street'. Postwar reforms might have allowed more local officers into the executive echelons of the bureaucracy, but with a population that was overwhelmingly nonEnglish speaking, even illiterate, the introduction of a merit-based system into a bureaucracy in which English was the lingua franca only perpetuated existing disconnectedness.

After the British grant of self-government in 1959, the newly elected PAP government initiated a series of measures that had far-reaching effects on the bureaucracy. To begin with, the Singapore Public Service, emerging from the colonial bureaucracy, was apprehensive about the seemingly pro-Chinese PAP. $^{5}$ Cuts to their pay and

4 Chief Secretary to Permanent Secretaries and Heads of Departments, CSO, CO215/53, Vol. III, 22 November 1956, MF862/1087.

5 A civil servant at that time recalled that 'when the PAP came in, the first fear was really the image which they had of being extreme, of being pro-communist and of being anti-civil service ... With such a strong political party coming in, with a certain amount of antagonism to the old Civil Service which has stood for the colonial masters and implemented the will of the colonial masters, to put it in the language of the extreme left, the running dogs of the British, what future was there for these civil servants?' (Goh Sin Tub, Oral interview transcript, NAS, Accession No. 001422, Reel 4: 39). 
a tightening of disciplinary regulations by the PAP soon after taking power led civil servants to protest and some even resigned (Singapore Government 1960). Senior officers were then sent to the newly set up Political Study Centre for courses on the context of policymaking since 'because of past training and background of the civil service in the traditions of the British system, particularly the colonial system ... they have not been made aware of the importance of keeping in touch with the masses' ${ }^{6}$

While the PAP's immediate measures might be an assertion of its authority over a hostile colonial-era bureaucracy, tightening of discipline - particularly anti-graft efforts - set in motion the eventual professionalisation of the bureaucracy. Socialisation of officers away from colonial apathy led to a public service consciousness of the importance of the context in which policies have to be formulated and implemented. Its 50 years of uninterrupted rule over the country also means that the PAP's initial claim of authority over the bureaucracy has over time cemented the centrality of its political control over the public service.

\section{The Administrative Service}

The Administrative Service is another colonial legacy, continuing to provide leadership for the Singapore bureaucracy. Its exact origin is not clear, but Seah (1971: 11a; see also Sim 1985; Lai 1995) believes it began with the 1882 introduction of the Eastern Cadetship, evolving into the Malayan Civil Service in 1934. The Singapore Administrative Service probably emerged as part of a distinct Singapore Civil Service after the island was separated from Malaya after World War II. Today, the officers of the Singapore Administrative Service continue to provide the senior leadership of the Singapore Public Service. Most permanent secretaries and chief executives heading the 15 ministries and 50 statutory boards are AOs. As of 2010, there were 277 AOs, constituting 0.2 per cent of the 127,000-strong public service (Ong 2011).

6 Singapore Government press statement, 'Civil service political study centre', 28 July 1959, JK/INFS.JL.119/59. 
In line with meritocratic principles, entrance into the apex of the Administrative Service is based on qualifications and is highly stringent. AOs are typically scouted from among the best and brightest of 18-year-old high school leavers. Those who excel academically and exhibit leadership abilities are offered Singaporean Government scholarships sponsoring their tertiary studies in prestigious overseas universities. On graduation, these 'scholars' are required to serve in the public service, typically in the Management Associates Program, in stints of three to four years at one or two government agencies (SAS n.d.(b)). If performance at these junior policy positions is deemed 'outstanding', they are then absorbed into the Administrative Service. AOs who do not perform to expectation during their probation of one to two years can choose other schemes of service in the public service. Entrance into the Administrative Service, in other words, is not direct and involves a highly rigorous process.

On confirmation of their appointment by the Public Service Commission, AOs are held to demanding standards as these generalists are rotated across the public service. Each posting spans two to three years to expose them 'to a broad spectrum of policy work and acquire knowledge, experience and expertise in government administration, economic, security and social fields' (Teo 2001). Regular postings are also meant to evaluate them in different job contexts for their suitability for promotion to senior positions. These postings and promotions are decided by the Special Personnel Board of senior permanent secretaries, whose standards are exacting. AOs who meet the standards after two to three postings are promoted to the SR9 grade as directors heading departments, typically at age 32 (Teo 2007; PSD 2010). The SR9 grade's $\$ \$ 365,000(A \$ 357,000)$ annual remuneration illustrates the policy of high pay to attract and retain talent. In comparison, the MX9 grade director in the general public service receives no more than $\$ \$ 264,000(\mathrm{~A} \$ 258,000) .{ }^{7}$ AOs with potential for higher leadership positions after two to three directorships are promoted into Public Sector Leadership - that is, chief executives of statutory boards and deputy and permanent secretaries of ministries.

$7 \quad$ While there are no official data on MX9 salaries, the monthly salary at the midpoint of MX9 grade was revealed as $\$ \$ 13,750(\mathrm{~A} \$ 13,400)$. Assuming the typical 13-month payment and three months' performance bonus, the annual salary of the mid-scale MX9 officer is $\$ \$ 220,000$ $(A \$ 215,000)$ (Teo 2012). Internet discussions listed the MX9 monthly salary range from $\$ 10,580$ to $\$ 16,540(\mathrm{~A} \$ 10,300$ to $\mathrm{A} \$ 16,200)$ and typical bonuses as four months (Salary Singapore 2011). 
However, if 'an officer's potential is assessed to be below that of at least deputy secretary when he reaches his mid-30s, he will be counselled to leave the Administrative Service' (Teo 2001: 5). The tenures of public sector leaders are capped at 10 years to allow leadership renewal but also to accommodate rapid mobility up the ranks.

Critics argue that AOs 'should work their way up' (Koh 2006; see also The Straits Times 2006; Loh 2007; Lim 2008). Rapid promotion and postings may have shielded AOs from experience implementing policies on the ground and working with everyday citizens. While they may excel at writing papers and table-top planning, some AOsdetractors allege - may lack 'soft skills' such as working with people: from members of the public to their staff and peers. The Public Service Division (PSD) clarified that AOs 'are subject to stricter requirements and higher expectations ... those who do not measure up to the high standards are asked to leave or transfer to another Service' (Ong 2007). In response to criticisms of AOs' high pay, the minister in charge of the civil service pointed out:

[T] here is no perfect method for doing this benchmarking ... We do not want pay to be the main reason for people to join us. But we also do not want pay to be the reason for them not to join us, or to leave after joining us. (Teo 2007)

\section{Training AOs}

Most of the training for AOs, as for other public service officers, is conducted by the Civil Service College (CSC). The CSC is a statutory board established by legislation specifically to provide training for the Singapore Public Service. Its status as a statutory board affords it greater autonomy than government ministries in areas such as financial arrangements and human resource management. For example, the CSC has the liberty to offer greater remuneration to attract staff. As with all statutory boards, the CSC reports to a parent ministry, which, appropriately, is the public service's Personnel Management Ministry, the PSD, which, in turn, is located within the Prime Minister's Office. Providing CSC management with oversight and strategic guidance is a board of directors. Chaired by the Permanent Secretary of the PSD, this board also includes permanent secretaries of several ministries, chief executives of other government agencies and senior executives from the private sector (CSC 2014). 
The CSC currently has three training departments. Apart from the international training arm, the two local training departments allow the CSC to train about 40,000 public officers each year, or one in every three officers (CSC 2008b: 9). The bulk of this training is conducted through the Institute of Public Administration and Management (IPAM). The range of courses caters to officers from Division 1 to Division 4, and includes induction skills training (human resource management, fiscal planning, information and communications technology, and so on) and pre-retirement planning - almost a cradle-to-grave offering of training in the career of a public officer (CSC 2008a).

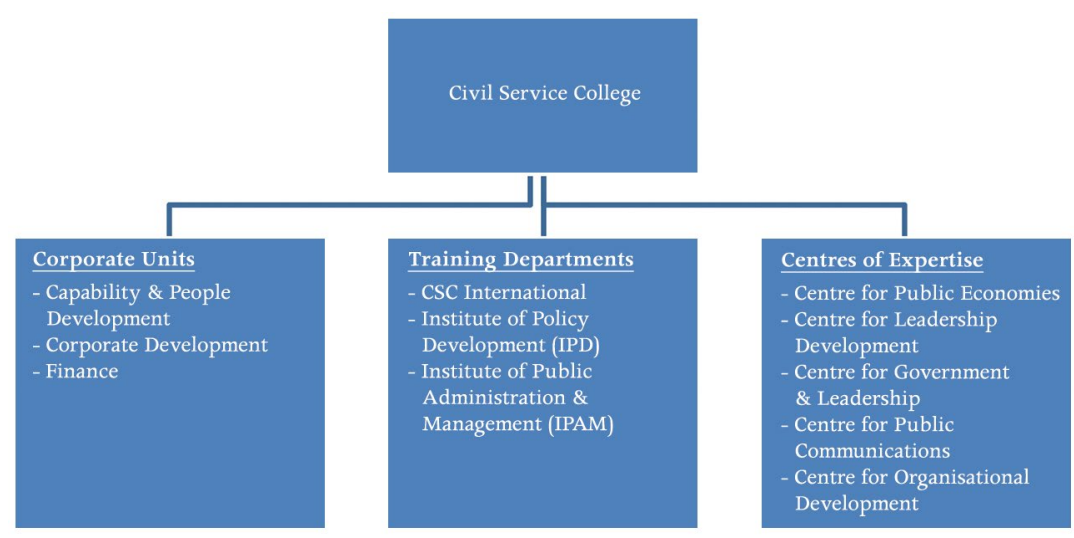

Figure 9.1: CSC organisational structure

Source: CSC (2013b).

\section{Institute of Policy Development}

The department in the CSC responsible for training AOs is the Institute of Policy Development. The IPD was established in 1993 as the original Civil Service College - a name it held until 1996, when it was renamed and merged with IPAM to form part of the current CSC (CSC 2013a).

From the start, the IPD was set up as a dedicated institute to provide leadership training for AOs (Hu 1992). Before 1993, their training had been conducted through the Civil Service Institute, IPAM's predecessor. The focus on skills training by the Civil Service Institute resulted in neglect of policymaking perspectives deemed critical for AOs as they rose through the ranks in their careers (Lai 1995: 33). 
The IPD, consequently, was established to provide AOs with specialised training in management, leadership, policy and strategic planning skills and to provide them with an international outlook.

Beyond skills training, the IPD's courses aimed to foster among AOs a sense of national teamwork. Pointing to France's Ecole Nationale d'Administration (ENA; National School of Administration) and Malaysia's National Institute of Public Administration (INTAN) as examples of where strong bonds were forged among elite administrators, the then Minister for Finance lamented that Singapore did not have a focal point to preserve traditions and transmit values. By bringing AOs together from their routine posts scattered across the bureaucracy, the IPD's courses could inculcate a sense of 'national team work necessary for the survival and progress of a small country like Singapore' (Hu 1992). Older AOs could share their 'baptism by fire' experiences with younger officers who did not have policymaking exposure (interview with Tan Boon Huat, cited Lai 1995: 33). The founding head of the IPD saw the institute as 'a repository of old wisdom, and as a generator of new ideas' (Mahbubani, cited in Lai 1995: 34). Its mission was spelled out as being:

To foster ... in addition to the prevailing strengths of competence, dedication, integrity and meritocracy ... a strong sense of tradition, esprit de corps, enhanced managerial skills, a sensitive understanding of the new evolving political and economic realities and commitment to a long term vision of a secure, stable and successful Singapore.

(Mission statement, cited in Lai 1995: 34)

While it is prepared to train participants in administrative skills, the IPD was clearly intended to imbibe within the Administrative Service elite a common sense of values and outlook - a goal that continues to feature prominently in the IPD's collateral material today.

The IPD's instructional objective appears geared towards providing practitioner-based policymaking lessons, rather than an academic curriculum. The IPD's original formulators aimed to draw on varied expertise to address its courses. In its collateral material, it states that the trainers engaged to share 'insights on governance, policy and leadership' are apparently 'senior public sector leaders' (CSC 2013a)that is, permanent secretaries and deputy secretaries of ministries and chief executives of statutory boards. Unlike trainers external to the bureaucracy, these public sector leaders are not paid for the 
training they conduct (Lai 1995; CSC 2013a), although time away from their offices to conduct such training constitutes a kind of crosssubsidy within the public service. Other speakers invited to engage with participants are leaders from the private sector. Throughout the IPD's website and publications, there is no reference to theoretical or academic frameworks in its programs.

The IPD offers a variety of training programs. These include policy forums that are used to keep officers abreast of 'live' policy issues so that 'officers are better prepared to think and act from a wider national perspective' (CSC 2011c). Workshops and seminars, such as the Strategic Perspectives Conference, where public sector leaders (that is, permanent secretaries, deputy secretaries and chief executives) engage with participants, 'engender shared understanding of national opportunities and challenges, and galvanise collective action' (CSC 2011d). Scenario Planning Workshops featured on the IPD's website are coorganised with the PSD's Strategic Policy Office to imbue in participants the aptitude 'to anticipate and deal with the challenges before they occur, and to harness opportunities that arise' (CSC 2011d).

\section{Milestone Programs}

The IPD's main mode of training for AOs are the Milestone Programs - a series of intensive training sessions extending for several weeks and scheduled at key points (or 'milestones') in an officer's career (CSC 2003: 26; 2005: 13, 44). A senior official in the PSD interviewed in the 1990s revealed that participants were identified and scheduled for Milestone Programs by the PSD based on their potential for higher responsibilities (interview with Tan Boon Huat, cited in Lai 1995: 54). The performance of these participants in the Milestone Programs would be used by the PSD as a reference point for their assessment.

As the medium of continuous training for AOs throughout their careers, these programs naturally focus on equipping AOs with several key competencies. In a work that probably enjoyed access to the CSC and the PSD, Saxena (2011: 107-8) compiled a list of competencies fundamental to developing management and leadership capacity among AOs: the capacity to be flexible and agile; an ability 
to analyse the macro/global situation and its relationship to micro/ local conditions; and being able to generate a variety of solutions and possibilities in diverse situations.

The types of Milestone Programs offered appear to have diversified in recent years as IPD's participant base has expanded beyond AOs to include officers in the mainstream public service who exhibit significant leadership potential. This chapter will focus on IPD's three main Milestone Programs for training AOs:

- Foundation Course

- Senior Management Program

- Leadership in Administration Program.

\section{The Foundation Course}

IPD's entry-level Milestone Program for AOs, the Foundation Course (FC), essentially exposes new AOs to the policymaking milieu. Sim (1985: 36) traced the FC's origins to 1979 when the Training Advisory Council observed that new Administrative Service recruits hailed from different universities locally and abroad. There was a need to acquaint these officers, particularly newly returned scholars, with Singapore's political, social, economic and administrative environments and those of its neighbouring countries. At the same time, the FC was intended to foster esprit de corps among the new officers. Though the FC was transferred to the IPD in 1993, having been run through the Civil Service Institute since its introduction, its aim remains to induct new AOs in the first year of their career. In recent years, the FC has reportedly been brought forward to the pre-absorption Management Associate Program phase (CSC 2007: 10, 36). In any case, participantsnewly returned graduates - would be in their mid-20s and probably in their first or second year in the public service.

During the nine-week course, new AOs and management associates are introduced to 'values, knowledge and skills' essential for leadership careers in the bureaucracy (CSC n.d.). These are drawn out through adventure learning, learning journeys, case studies, workshops, selffacilitated discussions on policy papers, role-play, presentations and dialogue with experts. The FC also includes overseas study trips to countries in the Association of Southeast Asian Nations (ASEAN). Besides equipping participants with an understanding of the 
South-East Asian neighbourhood, these trips allow officers to foster good relations with the foreign officials hosting them. In a 2003 interview, Bilahari Kausikan, a permanent secretary in the Ministry of Foreign Affairs, summed up the FC experience:

When you join there is a Foundation Course for Administrative Service Officer[s] from all ministries. They have a formal program given to all ministries and they will be taken around to a good number of ASEAN countries to visit our missions there and so on. When you go around with a bunch of fellows for three months a certain bonding occurs and it's meant to occur. (Barr and Skrbis 2008: 229)

\section{The Senior Management Program}

The Senior Management Program (SMP) is a six-week course for director-level officers focusing on policy implementation and preparing officers for future leadership positions (CSC 2006: 17). AOs would form the bulk of participants although the class would also include director-level officers from the mainstream civil service, identified by the PSD to have potential for senior appointments (interview with Zee Yong Kang, cited in Lai 1995: 39). This mixture of AOs with other emerging leaders of the civil service would serve the purpose of building team spirit and cohesion among the administrative elite, as well as bringing broader perspectives to the classroom. With the SR9 grade of AO directors pegged at age 32 and AOs reaching director grade after two to three postings of two to three years each, most participants would be in their early to mid-30s, having served about six to eight years in the Administrative Service. The syllabus concentrates on the finer details of translating policy intent at the strategic level to implementation as well as public consultation and public communications. The curriculum appears to have high-level inputs, as evidenced in a 2007 report. Themes for that year's SMP were apparently drawn up from 'Public sector leaders advance, a discussion involving senior officials [topics discussed included sustaining] good governance, forging new social compact, ensuring security and globalization, and hyper-competition' (cited in CSC 2008b: 26). Like other Milestone Programs, SMPs involve meetings and discussions with policymakers and leading personalities in the media and private sector (CSC 2006: 17). India and China are typical destinations for the SMP's overseas study trips, perhaps in view of their rising economic status and geostrategic implications for Singapore's regional 
environment. As revealed by an IPD official in the 1990s, while the SMP does not guarantee participants automatic promotion, it is almost a prerequisite for their progress to the next grade (interview with Zee, cited in Lai 1995: 39).

\section{The Leadership in Administration Program}

The IPD's pinnacle Milestone Program, the Leadership in Administration Program (LAP), spans five to six weeks and aims to prepare a cohort of about 25 officers at deputy secretary and chief executive level for permanent secretary positions - the highest office in the Singapore Public Service (CSC 2007: 36). Based on an AO's typical advancement through two to three rotations across the public service, participants would have spent between four and six years as directors before attending LAP and so would be in their mid-40s. As in the SMP it would not be surprising to find some LAP participants from the mainstream public service and so older in age given their slower career progression compared with that of AOs. Such a mixture of participants is in keeping with the intention to bring a diversity of experiences into the classroom and to strengthen esprit de corps among these bureaucratic elite, although there is no information in the public domain to confirm this.

The syllabus seeks to stimulate participants to think critically about the future of Singapore and how the public service should respond, and reviews fundamental principles that will project Singapore forward (CSC 2007: 36). Much attention is also given to processes and challenges in policy implementation, organisational leadership, management skills, and understanding prevailing trends in the political, economic and social sectors as well as the region around Singapore. Emphasis has in recent years been devoted to facilitating whole-of-government coordination and organisational change. During study trips to China and India, arrangements are made for participants to meet with fellow public sector leaders in the region. Permanent Secretary Bilahari recalls 'at the most senior level you have six weeks with a bunch of peers. Basically that is a far more conscious process of bonding, or elite formation if you want' (Barr and Skrbis 2008: 244). 


\section{Other types of Milestone Programs}

In 2008, a new Milestone Program called the Leadership Development Program (LDP) was introduced between the FC and the SMP. The AOs targeted would probably be in their late 20s or about 30, after spending two to three years at junior policy positions following their FC stint, and before promotion to directors. The LDP, in the words of the head of the civil service, 'helps young Administrative Officers to develop an understanding of self, cultivate the ability to develop others, build teams and to drive change' (Ho 2009).

In 2009, 'BEACON' was rolled out for newly appointed management associates. It aims to raise their 'self-awareness ... by giving them a better understanding of their personal strengths and areas of development' (Ho 2010). No further information could be obtained about this program, including what the abbreviation BEACON might represent. While management associates have their own dedicated Milestone Program, it is not clear whether they are then excluded from the FC, to make that course a Milestone Program focusing only on newly absorbed AOs.

\section{Funding}

While there is no publicly available information on the funding of these Milestone Programs for the AOs, IPAM's Training Directory offers a hint. IPAM's Strategic LEAD Program for directors from the mainstream public service is priced at $\$ \$ 2,782(\mathrm{~A} \$ 2,720)$ per participant (CSC 2008a: 24-5). However, the Strategic LEAD Program is a five-day course while IPD's SMP spans six weeks. Without more details of each program, simply multiplying the price of the Strategic LEAD Program with the six weeks of the SMP is speculative and not a meaningful deduction. Suffice to note that even this simplistic calculation would mean a very high price per participant. Factor in the costs involved in overseas study trips and the opportunity costs of the time given by senior public sector leaders and the investment in the training of AOs is undoubtedly high.

There is evidence to suggest that at least part of the funding for IPD's Milestone Programs is borne by the PSD. For IPAM's training programs, the participants or their agencies pay half the course fee. The remaining half is paid by the PSD through its Public Service 
for the 21st Century Office (PS21 Office), which is responsible for leading changes across the bureaucracy (PSD 2011). Indeed, as the parent ministry of the CSC and the personnel management arm of the public service, the PSD is certainly a source of funding for the CSC's training programs. In the 2011 Singapore Government Budget, the PSD reported allocating 'S\$24.6 million [A \$24.06 million] for the development of training programs, enhancement of methodologies and tools for public sector leadership development, organisational and employee development, as well as staff selection and assessment ${ }^{\prime}$ (Ministry of Finance 2011).

This amount is clearly in addition to the regular training subsidy provided by the PS21 Office for an individual officer's development. With the IPD the primary training arm of the Administrative Service, part of this budgetary allocation - especially that relating to 'public sector leadership development' — should go towards funding the IPD's Milestone Programs for AOs.

A more significant observation that can be drawn from the review of financial data is that a steady stream of funding for training is provided regardless of national economic performance. Even during periods when Singapore suffered recession - in 2003 as a result of the Severe Acute Respiratory Syndrome (SARS) epidemic, and between 2008 and 2009 after the Global Financial Crisis - the CSC's revenue from training was healthy (see Table 9.1). In fact, the CSC's income from training in 2008 and 2009 grew substantially, to $\$ \$ 35$ million (A $\$ 34.2$ million) and $\$ \$ 36$ million (A $\$ 35.2$ million) respectively, when compared with figures in the preceding three years (CSC 2010: 12). A review of the CSC's annual reports for these periods also indicates that the IPD continued with its scheduled Milestone Programs for AOs without any sign of disruption from the economic fallout. Singapore's commitment to providing training for its AOs, and officers across the public service generally, is evidently firm regardless of the country's economic conditions. 
Table 9.1: CSC revenue from training

\begin{tabular}{|l|c|c|c|c|c|c|c|c|}
\hline & 2002 & 2003 & 2004 & 2005 & 2006 & 2007 & 2008 & 2009 \\
\hline $\begin{array}{l}\text { Revenue } \\
\text { from training }\end{array}$ & $\mathrm{S} \$ 38 \mathrm{~m}$ & $\mathrm{~S} \$ 34 \mathrm{~m}$ & $\mathrm{~S} \$ 34 \mathrm{~m}$ & $\mathrm{~S} \$ 30 \mathrm{~m}$ & $\mathrm{~S} \$ 27 \mathrm{~m}$ & $\mathrm{~S} \$ 26 \mathrm{~m}$ & $\mathrm{~S} \$ 35 \mathrm{~m}$ & $\mathrm{~S} \$ 36 \mathrm{~m}$ \\
\hline $\begin{array}{l}\text { Income from } \\
\text { consultancy }\end{array}$ & $\mathrm{S} \$ 3 \mathrm{~m}$ & $\mathrm{~S} \$ 3$ & $\mathrm{~S} \$ 4 \mathrm{~m}$ & $\mathrm{~S} \$ 5 \mathrm{~m}$ & $\mathrm{~S} \$ 8 \mathrm{~m}$ & $\mathrm{~S} \$ 9 \mathrm{~m}$ & $\mathrm{~S} \$ 7 \mathrm{~m}$ & $\mathrm{~S} \$ 2 \mathrm{~m}$ \\
\hline Research & $\mathrm{n} / \mathrm{a}$ & $\mathrm{n} / \mathrm{a}$ & $\mathrm{n} / \mathrm{a}$ & $\mathrm{S} \$ 1 \mathrm{~m}$ & $\mathrm{~S} \$ 2 \mathrm{~m}$ & $\mathrm{~S} \$ 2 \mathrm{~m}$ & $\mathrm{n} . \mathrm{a}$. & $\mathrm{n} . \mathrm{a}$. \\
\hline $\begin{array}{l}\text { Government } \\
\text { grant }\end{array}$ & $\mathrm{n} / \mathrm{a}$ & $\mathrm{n} / \mathrm{a}$ & $\mathrm{n} / \mathrm{a}$ & $\mathrm{n} / \mathrm{a}$ & $\mathrm{n} / \mathrm{a}$ & $\mathrm{S} \$ 5 \mathrm{~m}$ & $\mathrm{~S} \$ 7 \mathrm{~m}$ & $\mathrm{~S} \$ 15 \mathrm{~m}$ \\
\hline $\begin{array}{l}\text { Other } \\
\text { income }\end{array}$ & $\mathrm{S} \$ 2 \mathrm{~m}$ & $\mathrm{~S} \$ 2 \mathrm{~m}$ & $\mathrm{~S} \$ 5 \mathrm{~m}$ & $\mathrm{~S} \$ 3 \mathrm{~m}$ & $\mathrm{~S} \$ 3 \mathrm{~m}$ & $\mathrm{~S} \$ 2 \mathrm{~m}$ & $\mathrm{~S} \$ 1 \mathrm{~m}$ & $\mathrm{~S} \$ 1 \mathrm{~m}$ \\
\hline $\begin{array}{l}\text { Total } \\
\text { revenue }\end{array}$ & $\mathrm{S} \$ 43 \mathrm{~m}$ & $\mathrm{~S} \$ 39 \mathrm{~m}$ & $\mathrm{~S} \$ 43 \mathrm{~m}$ & $\mathrm{~S} \$ 39 \mathrm{~m}$ & $\mathrm{~S} \$ 40 \mathrm{~m}$ & $\mathrm{~S} \$ 42 \mathrm{~m}$ & $\mathrm{~S} \$ 50 \mathrm{~m}$ & $\mathrm{~S} \$ 54 \mathrm{~m}$ \\
\hline $\begin{array}{l}\text { Training as a } \\
\text { percentage } \\
\text { of total }\end{array}$ & $88.37 \%$ & $87.18 \%$ & $79.07 \%$ & $76.92 \%$ & $67.50 \%$ & $61.90 \%$ & $70.00 \%$ & $66.67 \%$ \\
\hline
\end{tabular}

n/a not applicable

n.a. not available

Source: CSC (2003, 2004, 2005, 2006, 2007, 2008b, 2009, 2010). ${ }^{8}$

\section{Evaluation, relevance and responsiveness}

Given the significant cost and time involved, including attention from public sector leadership, some form of evaluation should be expected for these Milestone Programs. While official evaluation of the IPD's Milestone Programs is not publicly available, Lai (1995: 41) reported that participants typically completed evaluation forms that 'are elaborate in order to assess their satisfaction with the course and if refinements are in order'. There were no written examinations because the IPD was not an academic institution. Official data in the public domain indicate that evaluation is based on participant feedback on a five-point rating. In the 2001-03 CSC Annual Report, LAP participants gave a score of 4.19 for the course, while the IPD's average rating in 2004 for all its programs was reported as 4.46 (CSC 2003: 29; 2006: 18). While in-depth evaluation is not available, the continuation of these expensive programs suggests they have been found effective and relevant by the bureaucracy.

8 The CSC stopped publishing revenue data after this period. 
The relevance of Milestone Programs appears to be a fundamental factor. Detailed documents on the design of specific sessions in these programs are once again not available. A study of references to these programs in public material reveals constant emphasis on 'practitioner perspective', 'implementation' of public policy, 'public consultation' and 'public communication'. Interestingly, such a focus on policy implementation and public engagement coincides with some of the starkest criticisms of AOs - that is, that they do not have sufficient exposure to the operational details of policy implementation due to their fast-track promotion and rapid job rotation, and that AOs lack the people skills to effectively interact and engage with members of the public. In a recent article, the director of the IPD reiterated this emphasis on the practitioner-based teaching model. By getting senior officers to recount their practical experiences with junior officers, 'sharing could legitimately encompass good practices as well as learning points from policies that did not pan out as anticipated' (Maniam 2011: 71).

More than the relevance of practical lessons learnt, these Milestone Programs are particularly useful as platforms of socialisation. As noted earlier, the process of putting groups of AOs together for several weeks, making them undergo intensive activities - whether classroombased discussions or overseas study trips - has the effect of forging a strong sense of bonding among them. A constant reinforcement of particular messages towards policymaking, even if these are practical approaches and devoid of ideology, could condition these AOs into a uniform world view of the milieu in which they need to formulate and implement policies. Periodic reunions in the form of more senior-level Milestone Programs as each cohort rises up their career ladder would serve to deepen the socialisation process and strengthen their sense of camaraderie. While 'group think' can be a real risk, at the same time such socialisation offers advantages in policymaking: it builds up a common language that facilitates communication and deliberation and develops a strong network of contacts, if not friendship, between the policymaking elite. Even as they are dispersed across various ministries throughout the bureaucracy, such informal bonds facilitate inter-agency collaboration increasingly necessitated by emerging issues of governance. In recent times, the IPD seems to purposefully 
position its Milestone Programs as platforms for cultivating such whole-of-government bonding among its AO participants. Maniam (2011: 71) writes:

The value of such interactions across agencies is both analytical, in inculcating understanding among future leaders of how government operates as a system, not just as discrete silos; as well as in the formation of social capital, through networks and bonds of trust developed over the various leadership programs.

Hence, the relevance of the Milestone Programs lies in their ability to relate the classroom curriculum to the actual policy work milieu, but also their ability - through the socialisation of the bureaucratic elite - to develop capacity for governance.

One way in which the CSC seeks to ensure the relevance of its Milestone Programs may be through actively engaging the leadership of the bureaucracy. As pointed out earlier, it was found that themes of a particular Milestone Program had been drawn up from a discussion of public sector leaders - that is, permanent secretaries, deputy secretaries and chief executives (CSC 2008b: 26). By involving them as trainers to directly engage with program participants, these senior officials would be able to impart real-life policy lessons: dilemmas of and debates about policy options, the intricacies and undocumented tacit details of policy implementation, possibly even lapses and blunders of certain policy episodes. The public sector leaders of other ministries and agencies who sit on the CSC's board of directors provide another quick channel of feedback to ensure the relevance of training. By virtue of their senior positions in the bureaucracy, these officials are naturally conscious of the key strategic issues facing the country and so would have an understanding of the needs of the public service. As 'end-users' of training coming from agencies whose officers have been dispatched and thus are able to assess the relevance and effectiveness of training, these public sector leaders would also be able to provide feedback on training and how it can be improved.

Whether by design or by coincidence, structuring the CSC as a subordinate agency of a strategic ministry such as the PSD may also have contributed to the relevance and responsiveness of its training. As a statutory board of the PSD, the CSC is exposed to direct and frequent interactions with the PSD - such as meetings and eventsexposing it to the range of human resource issues and priorities facing 
the division. Another interesting observation is that several key members of CSC's senior management hold concurrent appointments in the PSD. For example, the dean and chief executive officer (CEO) of the CSC is concurrently deputy secretary (development) in the PSD (highlighted in Figure 9.2). The CSC's director of the Centre for Governance and Leadership was at the same time the director of the PSD's Strategic Policy Office. Such concurrent appointments at the training agency and the central ministry, and locating the training institution within the ambit of the ministry, link up the training institution with the strategic level of the bureaucracy to ensure training is relevant.

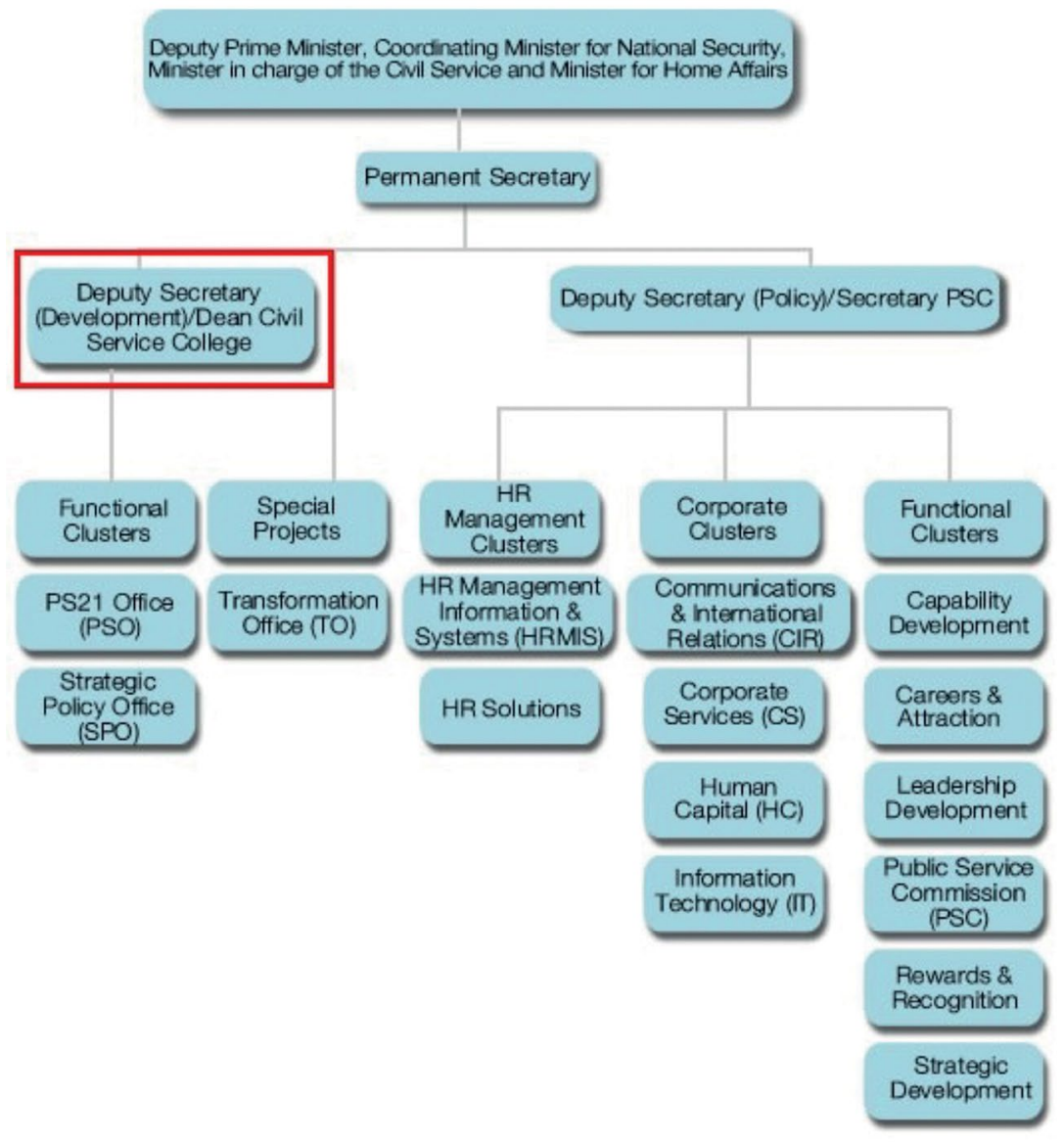

Figure 9.2: PSD organisational chart

Source: CSC (2011b). 
From the PSD's perspective, these Milestone Programs serve a broader personnel management purpose beyond the development of AOs. To be sure, Milestone Programs constitute the centrepiece in the suite of continuous training and development programs for AOs. ${ }^{9}$ When included in recruitment collateral, these programs and continuous training opportunities become a marketing tool to attract talented candidates into the Administrative Service. The PSD could effectively use Milestone Programs as an incentive - or a disincentive, by withholding an officer's nomination for a program-alongside performance appraisal and promotion as a tool for personnel management. Milestone Programs thus constitute an important part of the PSD's strategy to attract, retain, assess and develop talent through the Administrative Service.

\section{Conclusion}

Capacity building is a complex and multidimensional undertaking (UNPAN 2006: 17) and may not have been the specific and deliberate goal of the Singapore Public Service. The country's stability and high standard of living today result from a wide-ranging approach to developing the economy, improving social services and securing its international relations while strengthening public administration, rather than a single goal to develop capacity for good governance. Nevertheless, the high level of professionalism-efficient, incorruptible and non-partisan - exhibited by the Singapore Public Service suggests it has over time developed a level of capacity for effective governance. ${ }^{10}$

That the public service is growing its capacity for effective governance is clearly evident from the training of the Administrative Service elite, as has been discussed in this chapter. The relevance and responsiveness of the Milestone Programs to the policy milieu and

9 These range from Community Attachment Programs for the young officer and postgraduate degree or executive programs as the officer progresses in their career, to serving as director on the governing boards of government-linked companies and statutory boards as a senior AO (SAS n.d.(a)).

10 'Governance' is defined by the United Nations as 'the exercise of economic, political and administrative authority to manage a country's affairs at all levels. It comprises the mechanisms, processes and institutions through which citizens and groups articulate their interests, exercise their legal rights, meet their obligations and mediate their differences' (UNPAN 2006: 3). 
shifting strategic directions show that the public service seeks to attune AOs to the context in which policies will have to be effectively formulated and implemented. The shunning of academic theories in favour of an emphasis on the practitioner's perspective reinforces the real-world context in which officers will have to deliberate on and deliver policies. Parallel to the curriculum, the fostering of esprit de corps between each cohort of AOs through spending long hours in class together also facilitates interagency cooperation or 'wholeof-government coordination' when addressing issues straddling multiple portfolios. At the same time, the many discussions of policy issues within the framework of 'baptism by fire' stories from senior public sector leaders at these Milestone Programs serve to orient AOs towards common values espoused by the bureaucracy such as public service and integrity. More significantly, for a small country fixated on nurturing talent amid its lack of natural resources, the Milestone Programs are part of a sophisticated strategy to attract, develop and retain the best and brightest among its citizenry to lead the bureaucracy. Thus, the training of executives in the Singapore bureaucracy is more than an end in itself; by helping to recruit and develop talent in the administrative elite, Milestone Programs for the Administrative Service are a mechanism for building capacity for good governance.

The unique aspects of the Singaporean context must be taken into account when attempting to derive any (universal) lessons from its experience in capacity building. Being such a small island with a relatively small population certainly aids administration. The Singapore Public Service involves one level of government that is not encumbered by the complications of municipal, provincial or federal systems. The Singapore bureaucracy has also benefited from the support of a consistently strong political leadership with the continuity of the ruling political party. Even in its support of training in the bureaucracy, as noted by one CSC official in the mid-1990s, 'when some senior officials were unwilling to attend some courses because of the demands of their jobs in the Ministry, the first Deputy Prime Minister was able to command their attendance' (interview with Zee, cited in Lai 1995: 36). The advantages afforded by compactness are not to dismiss or downplay the complexities of administration faced by the Singapore bureaucracy; indeed, these phenomena may create their own sets of issues, which are beyond the scope of this 
chapter. Suffice to note that part of the rise in professionalism is aided by Singapore's unique geographical and political context. Rather than offering lessons, perhaps this chapter can conclude with some observations.

Singapore's experience suggests that the relevance and responsiveness of training can be aided by facilitative structures. Locating training institutions under the oversight of key strategic agencies allows broad or overarching goals to be quickly communicated to training institutions, for translation into a curriculum aligned with strategic objectives. Changing priorities can be similarly cascaded and training rapidly adjusted. In Singapore's case, apart from locating CSC within the ambit of the PSD, appointing leaders in the CSC to concurrent positions within the PSD undoubtedly facilitates communication between the personnel management ministry and its training agency. Such organisational structures can help align training so that it is more relevant and responsive to the broader priorities of the bureaucracy.

Another observation of the Singapore Public Service is the heavy involvement of its public sector leadership in the training process. Permanent secretaries and deputy secretaries by virtue of their positions of office are highly attuned to the strategic issues facing the country and the bureaucracy. They are in the best position to design training programs that will prepare young leaders to deal with these issues. Indeed, public sector leaders are by far the best trainers to impart real-life policy lessons from dilemmas and debates they have themselves experienced. The price of this dedication to leadership development is naturally the opportunity cost to bureaucratic leadership doing what they are supposed to do: lead, rather than train. Singapore has somehow managed to strike a delicate balance, involving permanent secretaries and chief executives, to keep the CSC's training relevant.

All governments have competing priorities and limited resources, and training in this context is often the victim of a more compelling agenda and lack of funding. In Singapore's case, the healthy state of its economy may have allowed it to invest heavily in the training of its public sector leaders even amid economic downturns. Nevertheless, the huge amount of money invested in developing these public sector leaders points to the importance accorded by the government to the bureaucracy, its leadership and the key role they play in the 
economy and the country. This discussion of Singapore's experience raises some questions for reflection: how important is the leadership to an organisation? How important is it for an organisation that their leadership is developed? How much money and time is an organisation willing to invest in its leaders and their development?

\section{References}

Barr, M. and Skrbis, Z. 2008. Constructing Singapore: Elitism, ethnicity and the nation-building project. Denmark: NIAS Press.

Chan, H. C. 1975. Politics in an administrative state: Where had the politics gone? In C. M. Seah (ed.), Trends in Singapore, 51-68. Singapore: Institute of South East Asian Studies.

Chew, E. and Lee, E. (eds) 1991. A History of Singapore. Singapore: Oxford University Press.

Civil Service College (CSC) n.d. Milestone Programs. Singapore: Civil Service College. Available from: cscollege.gov.sg/page. asp?id=55\&pf- $=1$ (accessed 6 June 2011) (site discontinued).

Civil Service College (CSC) 2003. Sharpening Minds Beyond Public Service Excellence: Civil Service College 2001-03. [Annual report]. Singapore: Civil Service College.

Civil Service College (CSC) 2004. Beyond Public Service Excellence, Moving Forward: Civil Service College 2003-04. [Annual report]. Singapore: Civil Service College.

Civil Service College (CSC) 2005. Renewing Our Commitment: Civil Service College 2004-05. [Annual report]. Singapore: Civil Service College.

Civil Service College (CSC) 2006. The Future: InSight-Civil Service College 2005-06. [Annual report] Singapore: Civil Service College.

Civil Service College (CSC) 2007. Developing People, Connecting the World: Civil Service College 2006-07. [Annual report] Singapore: Civil Service College. 
Civil Service College (CSC) 2008a. Institute of Public Administration and Management: Training directory 2008. Singapore: Civil Service College.

Civil Service College (CSC) 2008b. Transformation: Civil Service College 2007-08. [Annual report] Singapore: Civil Service College.

Civil Service College (CSC) 2009. Annual Report 2008-09. Singapore: Civil Service College.

Civil Service College (CSC) 2010. Annual Report 2009-10. Singapore: Civil Service College.

Civil Service College (CSC) 2011a. Official website. Singapore: Civil Service College. Available from: cscollege.gov.sg (accessed 22 August 2011).

Civil Service College (CSC) 2011 b. Management Team. Singapore: Civil Service College. Available from: cscollege.gov.sg/page.asp?id=32 (accessed 22 August 2011) (site discontinued).

Civil Service College (CSC) 2011c. Policy Forums. Singapore: Civil Service College. Available from: cscollege.gov.sg/page.asp?id=164 (accessed 6 June 2011) (site discontinued).

Civil Service College (CSC) $2011 \mathrm{~d}$. Workshops and Seminars. Singapore: Civil Service College. Available from: cscollege.gov.sg/page. asp?id=163 (accessed 6 June 2011) (site discontinued).

Civil Service College (CSC) 2013a. History of CSC. Singapore: Civil Service College. Available from: cscollege.gov.sg/About\%20Us/ Pages/Our-History.aspx (accessed 6 June 2011).

Civil Service College (CSC) 2013b. Organisational Structure. 1 April. Singapore: Civil Service College. Available from: cscollege.gov. sg/About\%20Us/Organisation \% 20Structure/Pages/default.aspx (accessed 6 June 2011).

Civil Service College (CSC) 2014. Board of Directors. Singapore: Civil Service College. Available from: cscollege.gov.sg/About \%20 Us/Organisation \%20Structure/Pages/Board-of-Directors.aspx (accessed 3 June 2014). 
Department of Statistics 1983. Economic and Social Statistics: Singapore 1960-1982. Singapore: Department of Statistics.

Department of Statistics 2011. Singapore in Figures 2011. Singapore: Department of Statistics. Available from: singstat.gov.sg/pubn/ reference/sif2011.pdf (accessed August 2011).

Drysdale, J. 1984. Singapore: Struggle for success. Singapore: Times Books International.

Ho, K. L. 2000. The Politics of Policy-Making in Singapore. Singapore: Oxford University Press.

Ho, P. 2009. Opening address by Head, Civil Service, 2009 Administrative Service Dinner and Promotion Ceremony, Public Service Division, Singapore, 30 March. Available from: app. psd.gov.sg/data/ASD percent2009percent20-percent20HCS percent20Speech.pdf(accessed November 2011)(site discontinued).

Ho, P. 2010. Opening address by Head, Civil Service, 2010 Administrative Service Dinner and Promotion Ceremony, Public Service Division, Singapore, 30 March. Available from: app.psd.gov. sg/data/Adminpercent20XServicepercent20Dinnerpercent202010p ercent20-percent20HCSpercent20Speech.pdf (accessed November 2011) (site discontinued).

$\mathrm{Hu}, \mathrm{R}$. 1992. Government setting up college for top civil servants. The Straits Times, 11 July.

Jones, D. S. 2002. Recent reforms in Singapore's administrative elite: Responding to the challenges of a rapidly changing economy and society. Asian Journal of Political Science 10(2): 70-93.

Koh, A. 2006. Scholars should work their way up. The Straits Times, 16 December.

Koh, G. 1997. Bureaucratic rationality in an evolving developmental state: Challenges to governance in Singapore. Asian Journal of Political Science 5(2): 114-41.

Lai, T. 1995. Administrative training in the Singapore civil service: An evaluation of recent changes. B.Soc.Sci.(Hons) academic exercise, National University of Singapore, Singapore. 
Lam, P. E. and Tan, K. Y. L. (eds) 1999. Lee's Lieutenants: Singapore's old guard. Sydney: Allen \& Unwin.

Latif, A. 2009. Lim Kim San: A builder of Singapore. Singapore: Institute of South East Asian Studies.

Lee, B. H. 1975. Statutory Boards in Singapore. Singapore: University of Singapore.

Lee, B. H. 1977. The Singapore Civil Service and its Perceptions of Time. Honolulu: University Microfilms International.

Lim, G. 2008. Young civil servants need course in street-cred. The Straits Times, 27 May.

Loh, M. (M. F.) 2007. Civil servants have the best of both worlds. The Straits Times, 6 March.

Maniam, A. 2011. Preparing public officers for new modes of governance. Ethos 10 (October): 66-71.

Mercer 2010. Quality of living worldwide city rankings 2010. Mercer. Available from: mercer.com/press-releases/quality-of-livingreport-2010 (accessed August 2011) (site discontinued).

Ministry of Finance 2011. Singapore Budget 2011: Expenditure overview, Prime Minister's Office. Singapore: Ministry of Finance. Available from: $\quad$ singaporebudget.gov.sg/budget_2011/expenditure_ overview/pmo.html (accessed August 2011).

Ng, I. 2010. The Singapore Lion: A biography of S. Rajaratnam. Singapore: Institute of South East Asian Studies.

Ong, P. 2011. Opening address, 2011 Administrative Service Dinner and Promotion Ceremony, Administrative Service, Singapore. Available from: adminservice.gov.sg/NR/rdonlyres/ BDD309D6-4EDE-4EA9-B988-AA21E5A86D4C/0/OpeningAddress byHeadCivilServiceMrPeterOngatthe23rdAdministrativeService DinnerandPro.pdf (accessed August 2011) (site discontinued).

Ong, T. H. 2007. Civil service is not an iron rice bowl. The Straits Times, 8 March. 
Public Service Division (PSD) 2010. Civil servants to get 2-month year-end payment. Press Release. Website. Available from: psd. gov.sg/data/ PSD\%20press\%20release\%2024112010.pdf (accessed August 2011) (site discontinued).

Public Service Division (PSD) 2011. Website. Available from: psd.gov. sg/ (accessed August 2011).

Quah, J. S. T. 1971. The Public Service Commission in Singapore: A comparative study of its evolution and its recruitment and selection procedures vis-a-vis the Public Service Commissions in Ceylon, India and Malaysia. M.Soc.Sci. thesis, Department of Political Science, University of Singapore.

Quah, J. S. T. 1972. Origin of Public Service Commission in Singapore. New Delhi: Indian Institute of Public Administration.

Quah, J. S. T. 1975. Administrative reform and development administration in Singapore: A comparative study of the Singapore Improvement Trust and the Housing and Development Board. PhD thesis, Florida State University, Tallahassee.

Quah, J. S. T. 1978. Administrative and Legal Measures for Combating Bureaucratic Corruption in Singapore. Singapore: Chopmen.

Quah, J. S. T. 1985. Statutory boards. In J. S. T. Quah, C. H. Chee and S. C. Meow (eds), Government and Politics of Singapore, 233-58. Singapore: Oxford University Press.

Quah, J. S. T. 1987. Public bureaucracy and policy implementation in Singapore. Southeast Asian Journal of Social Science 15(2): 77-95.

Quah, J. S. T. 1989. Singapore's experience in curbing corruption. In A. J. Heidenheimer, M. Johnston and V. LeVine (eds), Political Corruption: A handbook, 841-53. New Brunswick, NJ: Transaction Books.

Quah, J. S. T. 1994. Improving the efficiency and productivity of the Singapore civil service. In J. P. Burns (ed.), Asian Civil Service Systems: Improving efficiency and productivity, 152-85. Singapore: Times Academic Press. 
Quah, J. S. T. 1996a. Decentralizing public personnel management: The case of the public sector in Singapore. In S. Kurosawa, T. Fujiwara and M. A. Reforma (eds), New Trends in Public Administration for the Asia-Pacific Region: Decentralization, 492-506. Tokyo: Local Autonomy College, Ministry of Home Affairs.

Quah, J. S. T. 1996b. Transforming the Singapore civil service for national development. In H. K. Asmerom and E. P. Reis (eds), Democratization and Bureaucratic Neutrality, 294-312. New York: St Martin's Press.

Quah, J. S. T. 2003. Singapore's anti-corruption strategy: Is this form of governance transferable to other Asian countries? In J. B. Kidd and F.-J. Richter (eds), Corruption and Governance in Asia, 180-97. Basingstoke, UK: Palgrave Macmillan.

Quah, J. S. T. 2010. Public Administration Singapore Style. Singapore: Talisman Publishing.

Salary Singapore 2011. Civil Service Pay Scale in Singapore. Singapore: Salary Singapore. Available from: salarysingapore.com/civilservice-pay-scale-in-singapore.html (accessed August 2011).

Saxena, N. C. 2011. Virtuous Cycles: The Singapore public service and national development. Singapore: United Nations Development Program.

Seah, C. M. 1971. Bureaucratic evolution and political change in an emerging nation: A case study of Singapore. PhD thesis, Victoria University of Manchester, Manchester.

Seah, C. M. 1999. The administrative state: Quo vadis? In L. Low (ed.), Singapore: Towards a developed status, 250-70. Singapore: Oxford University Press.

Sim, S. H. 1985. Training in the Singapore Administrative Service. B.Soc.Sci.(Hons) academic exercise, National University of Singapore, Singapore.

Simon, H. A. 1976. Administrative Behaviour: A study of decisionmaking processes in administrative organisation. New York: The Free Press. 
Singapore Administrative Service (SAS) n.d.(a). Continuous Training for the Administrative Service. Singapore: Singapore Administrative Service. Available from: adminservice.gov.sg/AS/TrainDev/ (accessed 17 August 2011) (site discontinued).

Singapore Administrative Service (SAS) n.d.(b). Website. Available from: adminservice.gov.sg (accessed August 2011) (site discontinued).

Singapore Government 1955. Singapore Annual Report 1954. Singapore: Government Printing Office.

Singapore Government 1960. Singapore Annual Report 1959. Singapore: Government Printing Office.

Siow, V. 1998. Training in the Singapore civil service: The way forward. B.Soc.Sci.(Hons) academic exercise, National University of Singapore, Singapore.

Spann, R. N. 1973. Public Administration in Australia. Sydney: V. C. N. Blight.

Tan, S. S. 2007. Goh Keng Swee: A portrait. Singapore: Editions Didier Millet.

Teo, C. H. 2007. Ministerial Statement by Minister for Defence, Annex 1. Parliamentary Debates Official Report, 9 April. Singapore. Available from: nas.gov.sg/archivesonline/speeches/view-html? filename $=20070409992 . \mathrm{htm}$ (accessed August 2011).

Teo, C. H. 2012. Closing speech by Deputy Minister, Coordinating Minister for National Security and Minister for Home Affairs, Parliamentary Debate on Political Salaries, 18 January. Available from: app.psd.gov.sg/data/DPM ClosingSpeech18 percent20Jan2012.pdf (accessed January 2012) (site discontinued).

Teo, E. 2001. The Singapore public service: A developmentoriented promotion system, Presentation to Conference on Career Development of Public Servants in the 21st Century, Taipei, 19-20 December. Available from: app.psd.gov.sg/data/ PSspeechTaipeiDec01SpCivilSvc.pdf (accessed August 2011) (site discontinued). 
The Straits Times 2006. Don't knock us, our rice bowls are not iron. The Straits Times, 16 December.

Turnbull, C. M. 1989. A History of Singapore, 1819-1988. Singapore: Oxford University Press.

United Nations Public Administration Network (UNPAN) 2005. Republic of Singapore: Public administration country profile. New York: United Nations Public Administration Network. Available from: unpanl.un.org/intradoc/groups/public/documents /un/unpan023321.pdf (accessed August 2011).

United Nations Public Administration Network (UNPAN) 2006. Definition of Basic Concepts and Terminologies in Governance and Public Administration. New York: Committee of Experts on Public Administration. Available from: unpanl.un.org/intradoc/groups/ public/documents/un/unpan022332.pdf (accessed August 2011).

World Economic Forum 2011. The Global Competitiveness Report 20102011. Geneva: World Economic Forum. Available from: weforum. org/docs/WEFGlobalCompetitivenessReport2009-10.pdf (accessed August 2011) (site discontinued). 
This text is taken from Sharpening the Sword of State: Building executive capacities in the public services of the Asia-Pacific, edited by Andrew Podger and John Wanna, published 2016 by ANU Press, The Australian National University, Canberra, Australia. 